\title{
Evaluation of Metabolic and Nutritional Status of Children with Autism Spectrum Disorders: Results of a Single Center in Turkey
}

\section{Otizm Spektrum Bozukluğu Olan Çocukların Metabolik ve Beslenme Durumlarının Değerlendirilmesi: Türkiye'de Tek Bir Merkezin Sonuçları}

\author{
Melike Ersoy ${ }^{1 \oplus}$, Mehmet Murat $^{2} \oplus$, Semra Yilmaz $^{3} \oplus$ \\ ${ }^{1}$ Department of Pediatric Metabolic Diseases, University of Health Sciences Turkey, Bakirkoy Dr Sadi Konuk Training And Research Hospital, \\ Istanbul, Turkey \\ ${ }^{2}$ Department of Pediatrics, University of Health Sciences Turkey, Bakirkoy Dr Sadi Konuk Training And Research Hospital, Istanbul, Turkey \\ ${ }^{3}$ Department of Child and Adolescent Psychiatry, University of Health Sciences Turkey, Bakirkoy Training And Research Hospital, Istanbul, \\ Turkey
}

Received: 08.04.2020 / Accepted: 17.08.2020 / Published Online: 30.09.2020

Cite as: Ersoy M, Murat M, Yilmaz S. Evaluation of metabolic and nutritional status of children with autism spectrum disorders: results of a single center in Turkey. Med J Bakirkoy 2020;16(3):231-9.

\section{ABSTRACT}

Objective: The aim of this study is to evaluate the presence of inherited metabolic disordes and metabolic dysfunction and also biomarkers of nutritional status in pediatric patients with autism spectrum disorders.

Method: Biochemical and metabolic screening analyzes of 239ASD diagnosed children who were admitted to the Pediatric Metabolic Diseases Outpatient Clinic in Bakırköy Dr. Sadi Konuk Training and Research Hospital between October 2014 and November 2017, were evaluated rectospectively. ASD diagnosis were done according to DSM-5 (APA, 2013) criteria.

Results: The mean age of the participants was $56 \pm 34$ months (19-168 months), and $77.4 \%$ of them were male. IMD was present in $3,4 \%$ ( $n$ : 8) which those were two mitochondrial diseases and the one each hyperprolinemia type 1(HPI-1), guanidinoacetatemethyltransferase (GAMT) deficiency, mild phenylketonuria, 3-methyl crotonyl CoA carboxylase deficiency (3-MCC), middle-chain fatty acid oxidation defect (MCAD), classic type homocystinuria (cystathionine b-synthase deficiency). Mitochondrial dysfunction sign was present in \% 5,4 ( $n: 13)$ of ASD cases. VitB12 level was high in 38\% (n: 79) and low in $1 \%(n: 2)$ of all patients. The $25-\mathrm{OH}$ vitamin D level was in normal range in $28.5 \%$ (n: 55$)$ and high in $71.5 \%$ (138) of cases. Folate level was high in $8.2 \%$ (n: 17) of cases and no participant had low levels of folate.

Conclusion: Evaluation of patients' metabolic profiles and nutrient levels with a standard panel in autism spectrum disorders will provide recognition of treatable metabolic diseases and acquired metabolic disorders.

Keywords: Autism spectrum disorders, inherited metabolic disorders, nutrition

Öz

Amaç: Bu çalışmanın amacı çocuk otizm spectrum bozukluğu hastalarında kalıtsal metabolik hastalık ve metabolik disfonksiyonun varlığı ile beslenme durumunun biyobelirteçlerini değerlendirmektir.

Yöntem: Ekim 2014-Kasım 2017 tarihleri arasında Bakırköy Dr. Sadi Konuk Eğitim ve Araștırma Hastanesi Cocuk Pediatrik Metabolik Hastalıklar Polikliniğine başvuran 239 ASD tanısı almış çocuğun biyokimyasal ve metabolik tarama analizleri rektospektif olarak incelendi. Bulgular: Katılımcıların ortalama yaşı 56 ay \pm 34 ay (19-168 ay) olup, bunların \% 77,4'ü erkekti. iki vaka mitokondriyal hastalık ve her birinden birer Hiperprolinemi tip 1(HPI-1), guanidinoasetatemetiltransferaz (GAMT) eksikliği, hafif fenilketonüri, 3-metil krotonil CoA karboksilaz eksikliği (3-MCC), orta zincirli yağ asidi oksidasyon defekti (MCAD), klasik tip homosistinüri (sistatiyonin B-sentaz eksikliği) olacak şekilde vakaların \%3,4'ine (n: 8) kalıtsal metabolik hastalık tanısı konuldu. ASD olgularının \% 5,4'ünde (n: 13) mitokondriyal disfonksiyon bulgusu mevcuttu. VitB12 düzeyi tüm hastaların\% 38'inde (n: 79) yüksek ve \% 1'inde (n: 2) düşüktü. 25-OH D vitamini düzeyi olguların\% 28.5'inde (n: 55) normal,\% 71.5'inde (138) yüksekti. Olguların \% 8.2'sinde (n: 17) folat düzeyi yüksekti ve hiçbir katılımcının folat düzeyi düşük bulunmadı.

Sonuç: Otizm spectrum bozukluklarında hastaların metabolik profilleri ve nutrient düzeylerinin standart bir panel ile değerlendirilmesi, tedavi edilebilir metabolik hastalıklar ve edinsel metabolik bozukların tanınmasını sağlayacaktır.

Anahtar kelimeler: Otizm spektrum bozuklukları, kalitsal metabolik bozukluklar, beslenme

Corresponding Author:

zeynepcey@hotmail.com
M. Ersoy 0000-0002-2316-0790

M. Murat 0000-0003-3946-7006
S. Yilmaz 0000-0002-6527-2432 


\section{INTRODUCTION}

Autism spectrum disorder (ASD) is a neurodevelopmental disorder characterized by impairments in reciprocal social communication and a tendency to engage in repetitive stereotyped patterns of behaviors, interests, and activities and restricted interests (1). Until the 1980's it was considered as a rare disorder seen approximately 4 per 10,000 children (2). Recent estimates provided by the US Center for Disease Control and Prevention show that ASD affects 168 per 1000 children aged 8 years ${ }^{(3)}$. Increased public awareness of the disorder and access to the specialists, increased diagnostic ability of the psychiatrists for mild forms of ASD and changes in the diagnostic criteria are among the reported reasons of this increasing frequency. On the other hand a real increase possibly inherent to environmental factors cannot be excluded (4).

Today the exact etiology of ASD remains poorly understood. A wide range of genetic variations and interactions of gene-gene and gene-environment are suggested to be responsible in ASD pathophysiology (5). Patient's individual features such as genetic background, sex, the intrauterine environment, and early life experience including neonatal infections are thought to influence the phenotypic expression of the genetic factors ${ }^{(6)}$. Moreover it has been suggested that possible interactions among pleiotropic genetic factors increase individual vulnerability to environ-

Table 1. Inherited metabolic disease presented with autism spectrum disorder.

\begin{tabular}{ll}
\hline Phenylketonuria & Cerebral Folate deficiency \\
\hline Homocysistinuria & Pridoxine deficiency \\
\hline Mitochondrial diseases & Propionic acidemia \\
\hline Cerebral creatinine deficiency & Urea cycle defects \\
\hline Mucopolysaccharidosis & $\begin{array}{l}\text { Adenylsuccinate lysase } \\
\text { deficiencies }\end{array}$ \\
\hline L-2-OH glutaric aciduria & $\begin{array}{l}\text { Succinate semialdehyde } \\
\text { dehydrogenase deficiency }\end{array}$ \\
\hline Lesch Nyhan Syndrome & $\begin{array}{l}\text { Dihydropyrimidine } \\
\text { dehydrogenase deficiency }\end{array}$ \\
\hline Smith-Lemli Opitz Syndrome & Cerebrotendinous xanthomatosis \\
\hline Congenital glycosylation defect & Neuronal ceroid lipofuscinoses \\
\hline
\end{tabular}

mental inputs, and finally lead to development of multiple systemic comorbidities including metabolic derangement ${ }^{(7)}$. Several inherited metabolic diseases (IMD), such as phenylketonuria, homocysistinuria, mitochondrial diseases and cerebral creatinine deficiency, have been found to be associated with ASD (Table 1). IMD has been reported in 2-5\% of patients with ASD ${ }^{(8,9)}$. In last decades researches have focused on metabolic problems including abnormal levels of some vitamines and biomarkers of mitochondrial dysfunction (MD) and oxidative stress, besides the presence of an exact or overt metabolic disease (10-13). Mitochonrial dysfunction may be primary or secondary. Primary mitochondrial dysfunction refers to mitochondrial dysfunction caused by a defect in a gene directly involved in the function of mitochondrial systems which impair ATP production and antioxidant pathways. Secondary mitochondrial dysfunction refers to some genetic, metabolic diseases other than mitochondrial disease and environmental toxicants which affect the mitochondrial systems indirectly. Rossignol \& Frye have shown that the presence of abnormal biomarker values, such as higher pyruvate and/or lactate levels, which indicate mitochondrial dysfunction are more frequently seen in ASD than in normal population, and this value is even much higher than the prevalence of metabolic disease ${ }^{(14)}$. Moreover Shoffner et al. investigated 28 ASD patients with a comorbid mitochondrial disease and showed that in this particular group of ASD patients regression history which commonly occurs after fever, is much more common than others without a mitochondrial disease ${ }^{(15)}$. The autistic regression may be a result of underlying but not overt MD which renders children vulnerable to external factors causing regression into ASD clinic ${ }^{(14)}$. Because today no definitive treatment for core symptoms of ASD is present and the only treatment method is educational approaches, finding out a treatable etiologic cause of metabolic disease or dysfunction especially in younger ASD patients, will significantly improve the prognosis of ASD.

Most of previous studies on ASD and metabolic dysfunction comorbidity have small sample sizes and they often examine a limited number of metabolic biomarkers. Moreover not all studies have demonstrated abnormal levels of biomarkers. Kosinovsky et al. have shown that none of the ASD cases has incre- 
ased levels of plasma ammonia, plasma amino acids, plasma lactic acid and pyruvic acid and urinary organic acid ${ }^{(16)}$. As far as we know, incidence of IMD in Turkish ASD patients has been examined in only one study which detected 9 cases with IMD among 300 ASD patients ${ }^{(17)}$. However this study has not examined the metabolic dysfunction other than a spesific disease state.

In this current study we aimed to evaluate the presence of IMD and metabolic dysfunction and also biomarkers of nutritional status in pediatric ASD patients. For this purpose, we planned to investigate biochemical (urea, ALT, AST, ammonia, lactate, uric acid, creatinine, vitamin $B_{12}$, ferritin, total homocysteine (tHcy), vitamin $D$ and folic acid) and metabolic screening (amino acids, carnitine / acylcarnitine profile and urine organic acids) analysis in a large sample of children with ASD diagnosis. We hypothesized that both the diagnosis of a specific IMD and abnormal levels in biomarkers indicating metabolic dysfunction were more frequent in patients diagnosed as ASD.

\section{MATERIAL and METHODS}

\section{Participants}

The study included children with diagnosis of ASD who were admitted to our Pediatric Metabolic Diseases Outpatient Clinic between October 2014 and November 2017. A total of 314 ASD patients were admitted to the clinic within this time period, and the study was completed with 239 cases after exclusion of cases with incomplete data. All patients had been referred from the child and adolescent psychiatry outpatient clinic of the same hospital, where they received the diagnosis of ASD according to DSM-5 (APA, 2013) criteria. The study was approved by the local Ethics Committiee with protocol number: 2018-06-13.

\section{Procedures}

Data related to sociodemographic, clinical and laboratory information including biochemical and metabolic screening analysis of participants were obtained from their files.

\section{Biochemical analysis}

Urea, ALT, AST, ammonia, lactate levels were analyzed by enzymatic method; uric acid by colorimetric method; and creatinine by modified Jaffe method.
Vitamin B12, ferritin, total homocysteine (tHcy), $25-\mathrm{OH}$ vitamin $\mathrm{D}$ was analyzed by immunenzymatic method; and folic acid by competitive binding principle method by Roche.

\section{Metabolic screening analysis}

Quantitative analysis of amino acids was performed by liquid chromotography - mass spectrometry (LC-MS-MS), and carnitine / acylcarnitine profile was analyzed by Tandem mass spectrometry (Tandem MS) method, and urineorganicacids bygaschromatographymass spectrometry (GC-MS) method by redox.

\section{Statistical analysis}

SPSS for Windows 23.0 version was used for the statistical analyses. Mann-Whitney $U$ test was used for continuous variables in paired groups. The difference analysis was evaluated by chi-square test in categorical variables with two or more groups. Statistical significance was accepted as $p<0.05$.

\section{RESULTS}

A total of 239 pediatric ASD patients were included in the study., and $77.4 \%$ of them were male. The mean age of the participants was $56 \pm 34$ months (age range was $19-168$ months).

\section{Biochemical analysis}

Blood urea level was low in $11.3 \%$ ( $\mathrm{n}: 24)$ of patients. These patients with low blood urea had normal levels of ammonia and glutamine. Blood uric acid level was low in $1.4 \%(n: 3)$ and high in $7.2 \%(n: 15)$ of all cases, however these abnormal levels were not associated with an IMD.

Blood creatinine level was low in $4.7 \%$ (n:10) and high in $4.7 \%(n: 10)$ of patients. One ASD patient was diagnosed as guanidinoacetate methyltransferase (GAMT) deficiency. Based on low creatinine levels, the diagnosis was made by molecular analysis.

Vitamin B12 level was high in 38\% (n:79) and low in $1 \%(n: 2)$ of all patients. The $25-\mathrm{OH}$ vitamin D level was within normal range in $28.5 \%$ ( $\mathrm{n}: 55$ ) and high in $71.5 \%$ (138) of cases. Folate level was high in $8.2 \%$ ( $n: 17)$ of cases and no participant had low levels of folate.

Homocysteine level was higher than normal limits in 
Table 2. Biochemical results of the patients.

\begin{tabular}{|c|c|c|}
\hline & $\begin{array}{c}\text { medium } \pm s s \\
n(\%)\end{array}$ & $\begin{array}{l}\text { Median } \\
\text { (min-max) }\end{array}$ \\
\hline Urea (mg/dl) & $\begin{array}{c}23,59 \pm 6,67 \\
\downarrow 24(\% 11,3) \\
\text { N } 185(\% 86,9) \\
\uparrow 4(\% 1,9)\end{array}$ & $23(6-46)$ \\
\hline \multirow[t]{2}{*}{ Uric acid (mg/dt) } & $\begin{array}{c}3,47 \pm 0,93 \\
\downarrow 3(\% 1,4) \\
\text { N } 190(\% 91,3) \\
\uparrow 15(\% 7,2)\end{array}$ & $3,4(1,2-8,1)$ \\
\hline & $\begin{array}{c}0,35 \pm 0,09 \\
\downarrow 10(\% 4,7) \\
\text { N } 192(\% 90,6) \\
\uparrow 10(\% 4,7)\end{array}$ & $0,35(0,12-0,69)$ \\
\hline ALT (IU/L) & $\begin{array}{c}16,44 \pm 7,93 \\
\text { N } 205(\% 97,6) \\
\text { 个 } 5(\% 2,4)\end{array}$ & $15(6-58)$ \\
\hline AST (IU/L) & $\begin{array}{c}32,98 \pm 11,01 \\
\text { N } 189(\% 90,9) \\
\uparrow 19(\% 9,1)\end{array}$ & $30,5(14-72)$ \\
\hline TSH $(\mu \mathrm{IU} / \mathrm{L})$ & $\begin{array}{c}2,64 \pm 1,34 \\
\text { N } 201(\% 96,2) \\
\quad \uparrow 8(\% 3,8)\end{array}$ & $2,35(0,64-9,5)$ \\
\hline FT4 (ng/dL) & $\begin{array}{c}1,31 \pm 0,18 \\
\text { N } 35(\% 16,7) \\
\uparrow 174(\% 83,3)\end{array}$ & $1,31(0,63-1,7)$ \\
\hline B12 (pg/mL) & $\begin{array}{c}507,76 \pm 320,96 \\
\downarrow 2(\% 1) \\
\text { N } 127(\% 61,1) \\
\uparrow 79(\% 38)\end{array}$ & 451 (117-1725) \\
\hline Ferritin $(\mu / L)$ & $\begin{array}{c}34,39 \pm 32,66 \\
\downarrow 66(\% 32,5) \\
\text { N } 136(\% 67) \\
\uparrow 1(\% 0,5)\end{array}$ & $28(4,6-359)$ \\
\hline Folat (ng/mL) & $\begin{array}{c}11,81 \pm 8,45 \\
\text { N } 190(\% 91,8) \\
\text { 个 } 17(\% 8,2)\end{array}$ & $11(3,5-112)$ \\
\hline $25 \mathrm{OH}$ vitamin $\mathrm{D}(\mathrm{ng} / \mathrm{mL})$ & $\begin{array}{c}28,65 \pm 13,54 \\
\text { N } 55(\% 28,5) \\
\uparrow 138(\% 71,5)\end{array}$ & $26(3,7-70)$ \\
\hline Homocysteine ( $\mu \mathrm{mol} / \mathrm{L})$ & $\begin{array}{c}6,67 \pm 2,47 \\
\downarrow 42(\% 20,6) \\
\text { N } 161(\% 78,9) \\
\uparrow 1(\% 0,5)\end{array}$ & $6(0-15)$ \\
\hline Laktate ( $\mu \mathrm{mg} / \mathrm{dL})$ & $\begin{array}{c}18,69 \pm 10,87 \\
\text { N } 132(\% 67,7) \\
\uparrow 62(\% 31,8)\end{array}$ & $15,8(0,01-68)$ \\
\hline Ammonia ( $\mu \mathrm{gr} / \mathrm{dL}$ ) & $\begin{array}{c}66,44 \pm 27,63 \\
\text { N } 166(\% 84,3) \\
\uparrow 26(\% 13,2)\end{array}$ & $61(12-209)$ \\
\hline
\end{tabular}

ALT: alanine transaminase, AST: aspartate transaminase, TSH: Thyroid stimulating hormone FT4: FreeT4 one $(0.5 \%)$ patient. This patient had high methionine level but normal vitamin B12 and folic acid levels, and was diagnosed as classic type homocystinuria (cystathionine $\beta$-synthase deficiency).

Blood lactate value was high in $31.8 \%$ ( $n: 62$ ) and urinary lactate level was high in $7.8 \%(n: 4)$ of cases. Two of these cases were diagnosed as mitochondrial disease. High blood ammonia level was present in $13.2 \%$ ( $n: 26)$ of cases. However, these elevations were not associated with an IMD (Table 2).

\section{Metabolic screening analysis}

Urine organic acid evaluation showed that increased pyruvic acid level was present in 9,8\% (n:5) and high levels of 5 -oxoproline in $15.7 \%$ ( $n: 8)$ of cases. Methylglutaric acid was elevated in $3(5 \%)$ patients including 2 patients diagnosed as mitochondrial disease and the third patient had mitochondrial dysfunction. Ethylmalonic acid level was (indicating mitochondrial dysfunction) high in $6.7 \%(n: 4)$ of cases. The 3-hydroxy-propionic acid level was elevated in $18.3 \%$ (n: 11 ) of cases. Mitochondrial dysfunction was detected in 3 cases (Table 3 ).

Table 3. Urine organic acid results of the patients.

\begin{tabular}{|c|c|c|}
\hline ( $\mu \mathrm{mol} / \mathrm{L})$ & $\begin{array}{c}\text { medium } \pm s s \\
n(\%)\end{array}$ & $\begin{array}{c}\text { Median } \\
(\text { min-max })\end{array}$ \\
\hline 2-Hydroxy-isovaleric acid & $\begin{array}{c}0,23 \pm 0,14 \\
\text { N } 60(\% 100)\end{array}$ & $0,2(0,2-0,88)$ \\
\hline 3-Hydroxy-propionic acid & $\begin{array}{l}25,04 \pm 29,59 \\
\text { N } 49(\% 81,7) \\
\uparrow 11(\% 18,3)\end{array}$ & $12(4-142)$ \\
\hline 3-Hydroxy-isovaleric acid & $\begin{array}{c}9,49 \pm 7,22 \\
\downarrow 58(\% 96,7) \\
\text { N } 2(\% 3,3)\end{array}$ & $5,8(2,96-44,2)$ \\
\hline 3-Methyl glutaconic acid & $\begin{array}{c}5,49 \pm 8,18 \\
\text { N } 57(\% 95) \\
\uparrow 3(\% 5)\end{array}$ & $6,65(3,5-38)$ \\
\hline Ethylmalaonic acid & $\begin{array}{c}6,49 \pm 7,22 \\
\text { N } 56(\% 93,4) \\
\uparrow 4(\% 6,6)\end{array}$ & $6,65(3,5-38)$ \\
\hline Piruvic acid & $\begin{array}{c}14,31 \pm 16,5 \\
\text { N } 44(\% 86,3) \\
\uparrow 5(\% 9,8)\end{array}$ & $11(4,32-117)$ \\
\hline Laktic acid (mmol/mol) & $\begin{array}{c}56,47 \pm 96,69 \\
\text { N } 14(\% 27,5) \\
\text { 个 } 4(\% 7,8)\end{array}$ & $24(4,5-429)$ \\
\hline 5-Oxoproline & $\begin{array}{c}124,33 \pm 407,93 \\
\text { N } 43(\% 84,3) \\
\uparrow 8(\% 15,7)\end{array}$ & $53(26-2960)$ \\
\hline
\end{tabular}


Table 2. Blood aminoacid and acylcarnitine profiles of the cases.

\begin{tabular}{|c|c|c|}
\hline$(\mu \mathrm{mol} / \mathrm{L})$ & $\begin{array}{c}\text { medium } \pm s s \\
n(\%)\end{array}$ & $\begin{array}{c}\text { Median } \\
\text { (min-max) }\end{array}$ \\
\hline Phenylalanine & $\begin{array}{l}78,62 \pm 20,41 \\
\text { N } 96(\% 74,4) \\
\uparrow 33(\% 25,6)\end{array}$ & 75 (35-149) \\
\hline Proline & $\begin{array}{c}220,74 \pm 106,45 \\
\text { N } 122(\% 94,6) \\
\uparrow 7(\% 5,4)\end{array}$ & $193(95-833)$ \\
\hline Glutamin & $\begin{array}{c}526,95 \pm 172,3 \\
\downarrow 6(\% 4,7) \\
\text { N } 117(\% 90,7) \\
\uparrow 6(\% 4,7)\end{array}$ & $531(169-1052)$ \\
\hline Alanine & $\begin{array}{c}410,5 \pm 172,72 \\
\downarrow 5(\% 3,9) \\
\text { N } 94(\% 72,9) \\
\uparrow 30(\% 23,3)\end{array}$ & $395(27-942)$ \\
\hline Glycine & $\begin{array}{c}298,63 \pm 146,42 \\
\text { N } 77(\% 62,1) \\
\uparrow 39(\% 31,5)\end{array}$ & $272,5(29,6-969)$ \\
\hline $\mathrm{CO}$ & $\begin{array}{c}31,68 \pm 10,66 \\
\text { N } 158(\% 100)\end{array}$ & $29(12-65)$ \\
\hline C3 (propionyl) & $\begin{array}{c}1,52 \pm 0,81 \\
\text { N } 158(\% 100)\end{array}$ & $1,39(0,34-5,45)$ \\
\hline C4 (butyryl) & $\begin{array}{c}0,24 \pm 0,2 \\
N 157(\% 99,4) \\
\uparrow 1(\% 0,6)\end{array}$ & $0,2(0,01-1,49)$ \\
\hline C4-OH (3-OH butyryl) & $\begin{array}{c}0,13 \pm 0,11 \\
\text { N } 158(\% 100)\end{array}$ & $0,1(0-0,66)$ \\
\hline C5 (isovaleryl) & $\begin{array}{c}0,14 \pm 0,09 \\
\text { N } 158(\% 100)\end{array}$ & $0,12(0,03-0,7)$ \\
\hline C5-OH (3-OH isovaleryl) & $\begin{array}{c}0,21 \pm 0,14 \\
\text { N } 157(\% 99,4) \\
\uparrow 1(\% 0,6)\end{array}$ & $0,18(0,01-1,18)$ \\
\hline C10:1 (decanoyl) & $\begin{array}{c}0,11 \pm 0,1 \\
\text { N } 157(\% 99,4) \\
\uparrow 1(\% 0,6)\end{array}$ & $0,09(0-0,99)$ \\
\hline C14:1 (tetradecanoyl) & $\begin{array}{c}0,07 \pm 0,08 \\
\text { N } 158(\% 100)\end{array}$ & $0,04(0,01-0,45)$ \\
\hline C14-OH (3-OH tetradecanoyl) & $\begin{array}{c}0,02 \pm 0,07 \\
\text { N } 157(\% 99,4) \\
\uparrow 1(\% 0,6)\end{array}$ & $0,01(0,01-0,91)$ \\
\hline
\end{tabular}

C: carnitine

Quantitative evaluation of serum amino acid profiles showed that; blood phenylalanine level was above normal limits in $25.6 \%$ ( $n: 33)$ of cases. Among them one patient was diagnosed as mild type phenylketonuria and two were diagnosed as hyperphenylalaninemia. High blood proline levels were present in 5.4 $\%(n: 7)$ of cases; one of them was diagnosed as hyperprolinemia type1 (HPI). Mitochondrial dysfunction was detected in 3 cases. High blood alanine level was present in $23.3 \%$ ( $\mathrm{n}: 30$ ) of cases, and among them 4 cases had mitochondrial dysfunction. Increased blood glycine level was present in 39 $(31.5 \%)$ cases but these increased levels were not associated with an IMD (Table 4).

Evaluations of carnitine/acylcarnitine profile demonstrated abnormal biomarker levels associated with a specific disease in two cases. One case $(0.6 \%)$ had high levels of $\mathrm{C} 5-\mathrm{OH}$ (3-OH isovaleryl) carnitine and was diagnosed as 3-MCC (3-methyl crotonyl CoA carboxylase deficiency). The other case $(0.6 \%)$ had high levels of C8, C10: 1 (decanoil) C10: 2 carnitine and was diagnosed as middle-chain fatty acid oxidation defect. One patient $(0.6 \%)$ had high levels of C14: 2 (tetradecadienoyl) and 3 cases (1.9\%) had high levels of $\mathrm{C} 14-\mathrm{OH}$ (3-OH tetradecadienoyl) carnitine but these elevated levels were not associated with a metabolic disease (Table 4).

Biochemical and metabolic screening analyzes of participants showed that IMD was present in $3.4 \%$ $(n: 8)$ and mitochondrial dysfunction in \% 5,4 (n:13) of ASD cases. Overall metabolic disarrangement was present in $8,8 \%$ of all participants.

\section{DISCUSSION}

Autism spectrum disorder is an important neurodevelopmental disorder with increasing frequency impairing the quality of life of the patients and their families. Many studies have demonstrated that IMD may present with autism symptoms. The diagnosis of underlying IMD may be delayed in patients without clinical findings other than autism findings ${ }^{(9)}$. In these ASD patients who have the chance of medical treatment, the detection of the underlying medical disease early in life significantly affects the outcome of ASD.

In this current study we found that IMD was present in $3.4 \%$ and abnormal biomarker levels indicating mitochondrial dysfunction not related to an overt disease in $5.4 \%$ of cases. Our findings related to IMD frequency are compatible with previous reports $(8,9,17)$. It has been reported that in ASD patients pre- 
sence of abnormal levels of mitochondrial biomarkers is much more common than presence of $\mathrm{MD}^{(14)}$. Our findings support that mitochondrial dysfunction, even it is not an overt disease state, plays an important role in the etiopathogenesis of ASD.

Biochemical analysis revealed abnormal findings related to levels of blood urea, uric acid and creatinine in some patients. Twenty-four (11.3\%) patients had decreased blood urea levels but their blood ammonia and / or glutamine levels were within normal range. Blood uric acid levels were abnormal in $8,6 \%$ of cases; three (1.4\%) patients had low levels and fifteen (7.2\%) patients had high levels of blood uric acid, but these abnormal levels were not associated with OCD. Further analysis was not performed in these patients with abnormal blood uric acid levels because none of them had clinical findings and persistent abnormal levels which are the criteria for recommendation for further analysis for uric acid metabolism disorders. Decreased urea levels are not only seen in urea cycle disorders but it is also observed also secondary to malnutrition ${ }^{(18)}$. Decreased urea levels and abnormal blood uric acid levels might be related to abnormal nutritional patterns related to restrictive and selective type food intake seen in ASD patients. For example insufficient protein intake due to abnormal feeding might be the cause of low urea levels in our ASD patients. Blood creatinine level was low in $4.7 \%(n: 10)$ and high in $4.7 \%(n: 10)$ of the cases. One patient was diagnosed with GAMT deficiency which is the most common creatinine metabolism defect. In approximately $80 \%$ of cases with GAMT deficiency any additional systemic finding other than behavior disorders such as autistic behavior and self-harm may not be present ${ }^{(19)}$. Since the treatment response and prognosis of these diseases depend on the age at which treatment is initiated, early diagnosis is an important issue.

Assessment of levels of vitamins among ASD patients showed that; in terms of vitamin B12 levels 38 $\%$ of the patients had increased and $1 \%$ had low levels of vitamin B12. Among the participants $8.2 \%$ had high folate level. None of them had low folate nor low vitamin $D$ levels. One patient had increased homocysteine levels with normal levels of vitamin B12 and folic acid, and was diagnosed as classic homocystinuria (cystathionine $\beta$-synthase defici- ency) because of high methionine levels. Contrary to expectations, B12, folic acid and vitamin D deficiency were not observed in our patients. Researchers suggest that deficiencies of these vitamins are important factors in the pathogenesis of ASD ${ }^{(20-22)}$. However in recent decade researches have demonstrated that in ASD patients increased oxidative stress due to metabolic or environmental effects may cause elevation of B12, which can explain our finding of elevated vitamin B12 levels ${ }^{(23,24)}$. Moreover our study was done in a clinical sample rather than in a populationbased sample. The reason why we could not find any deficiency in vitamin B12, folic acid and vitamin D levels may be due to the fact that these deficiencies have been treated in previous visits to physicians.

In last decades many researches have focused on the mitochondrial function in the pathophysiology of ASD. It is known that mitochondrial dysfunction may lead to autism ${ }^{(25)}$. Several studies have demonstrated that mitochondrial dysfunctions reduce intracellular energy production, increase oxidative stress, and lead to a decrease in neurogenesis and postsynaptic neurotransmitter release ${ }^{(11-14,25,26)}$. In a recent epidemiological study, the probability of development of autism in the presence of mitochondrial disease has been found to be 550-770 times higher than in the normal population ${ }^{(15)}$. In another study conducted with 25 ASD patients with coexisting mitochondrial dysfunction, authors found that these specific groups of ASD patients had at least some physical examination findings suggesting mitochondriopathy in contrast to patients with idiopathic autism. Clinical aspects of mitochondrial dysfunction in autism spectrum disorder (ASD) include unusual neurodevelopmental regression in clinic presentation, especially if triggered by an inflammatory event, gastrointestinal symptoms, seizures, motor delays, fatigue and lethargy ${ }^{(25,27)}$. Therefore, it is appropriate to examine the clues of metabolic disease more carefully in the clinical evaluations of children with ASD diagnosis, especially in patients with regression history. However in our study in 13 ASD patients (5.4 $\%)$ with abnormal biochemical or metabolic screening results any of these defined clinical/physical signs were not present. Some ASD diagnosed children with comorbid mitochondrial dysfunction, may have no clinical/physical finding and no abnormality in the levels of biomarkers such as lactate. 
Mitochondrial dysfunction does not always occur as a result of genetic defect, rather it can be acquired secondary to adverse environmental effects which induce oxidative stress ${ }^{(28)}$. Moreover other geneticmetabolic diseases and environmental factors (food, radio, etc.) as well as primary mitochondrial diseases, can cause mitochondrial dysfunction. According to different hypothesis, oxidative stress due to mitochondrial dysfunction and poor ATP production may contribute to Rett Syndrome which is associated with autism clinic ${ }^{(29)}$. Moreover stressors, such as dehydration, fever and infection can lead to a functional decline and neurodegenerative regression in individuals with underlying but not overt MD ${ }^{(25)}$. Some patients with ASD phenotypes clearly show some clinical features of the genetic-based primary MD ${ }^{(30)}$. These include an elevated plasma L-lactate, urine metabolites (such as ethylmalonic acid, 3-methylglutaric acid) biochemical evidence of mitochondrial dysfunction, elevated pyruvate, and alanine levels. Besides, a history of regression in ASD manifestations and presence of multiorgan disorders should alert clinicians to the possibility of MD in autism (27). Thus, the identification of children with ASD/MD is important since each type of IMD or MD associated with different metabolites has its own specific treatment ${ }^{(11)}$.

Evaluations of blood aminoasit and carnitine / acylcarnitine profile revealed that increased blood phenylalanine levels were present in $25.6 \%$ ( $\mathrm{n}: 33$ ) cases. Among these cases one patient was diagnosed as mild type phenylketonuria and two cases as hyperphenylalaninemia. $\mathrm{C} 5-\mathrm{OH}(3-\mathrm{OH}$ isovaleryl) carnitine was detected in $0.6 \%$ ( $n: 1)$ of the cases who were diagnosed as 3-MMC. Higher levels of C8 (octanoyl) and C10: 1 (decanoyl) C10: 2 (dekadodienoyil) carnitine were found in $0.6 \%$ ( $n: 1)$ of cases who was diagnosed as mid-chain fatty acid oxidation defect (MCAD).

The association of ASD with late diagnosed PKU is well known. It has been reported that in patients with phenylketonuria diet therapy has a corrective effect on the autism symptoms ${ }^{(31,32)}$. The $3-\mathrm{MCC}$ is generally diagnosed in older ages and manifests signs of psychosocial regression and fatigue (Cho et al 2016). MCAD is the most common fatty acid oxidation disorder. Although patients present with hypoketotic hypoglycemia, a significant proportion of patients with gene- tic diagnosis remain lifelong asymptomatic (33,34). MCAD is a common disease in the population and can be observed without any symptoms. In order to determine the relationship between MCAD and ASD, studies should be done in larger groups.

\section{Study limitations}

Our study was not a prospective study, and had a retrospective design without any control group. Because information related to autism severity and its clinic (whether the patient had autism regression) were not included in the files of all patients the relationship between metabolic dysfunction and these two conditions could not be examined in this study.

\section{CONCLUSION}

Recently the researches on the etiopathogenesis of ASD have focused on the metabolic disarrengements. The results of our autism panel examination in pediatric ASD patients showed that IMD was present in 3,4\% and mitochondrial dysfunction in 5,4\% of participants. Overall $8,8 \%$ of all ASD patients had abnormal metabolic findings. Today ASD has no medical treatment for its core symptoms. Finding out an underlying curable metabolic condition will allow an important chance for medical treatment of ASD, at least for reducing its clinical severity. A standard metabolic screening program for ASD has not been established yet. We think by the recent progresses in diagnostic methods we will see better the actual higher frequency of metabolic problems associated with ASD. In order to understand whether these metabolic problems are whether cause or result of ASD, studies conducted with elaborate and large samples are needed.

\section{Acknowlegment}

This study has not received any financial and/or material support. We thank all patients and their parents for agreeing to participate in this study.

Ethics Committee Approval: The study was approved by the local Ethics Committiee with protocol number: 2018-06-13.

Conflict of interest: There is no conflict of interest. Funding: This work did not receive any funding. Informed consent: These patients and tehir parents provided informed consent for publication of this study. 


\section{REFERENCES}

1. Maenner MJ, Rice CE, Arneson CL, Cunniff C, Schieve LA, Carpenter LA, et al. Potential impact of DSM-5 criteria on autism spectrum disorder prevalence estimates. JAMA Psychiatry. 2014;71(3):292-300. https://doi.org/10.1001/jamapsychiatry.2013.3893

2. Fombonne E. Epidemiology of autistic disorder and other pervasive developmental disorders. J Clin Psychiatry. 2005;66 Suppl 10:3-8. PMID: 16401144.

3. Baio J, Wiggins L, Christensen DL, Maenner MJ, Daniels J, Warren Z, et al. Prevalence of Autism Spectrum Disorder Among Children Aged 8 Years - Autism and Developmental Disabilities Monitoring Network, 11 Sites, United States, 2014. MMWR Surveill Summ. 2018;67(6):1-23. https://doi.org/10.15585/mmwr.ss6706a1

4. Palmieri L, Persico AM. Mitochondrial dysfunction in autism spectrum disorders: cause or effect? Biochim Biophys Acta. 2010;1797(6-7):1130-7. https://doi.org/10.1016/j.bbabio.2010.04.018

5. Yoo H. Genetics of autism spectrum disorder: current status and possible clinical applications. Exp Neurobiol. 2015;24(4):257-72.

https://doi.org/10.5607/en.2015.24.4.257

6. Constantino JN, Charman T. Diagnosis of autism spectrum disorder: reconciling the syndrome, its diverse origins, and variation in expression. Lancet Neurol. 2016;15(3):279-91.

https://doi.org/10.1016/S1474-4422(15)00151-9

7. Barone R, Alaimo S, Messina M, et al. A Subset of patients with autism spectrum disorders show a distinctive metabolic profile by dried blood spot analyses. Front Psychiatry. 2018;9:636. https://doi.org/10.3389/fpsyt.2018.00636

8. Ververi A, Vargiami E, Papadopoulou V, et al. Clinical and laboratory data in a sample of greek children with autism spectrum disorders. J Autism Dev Disord. 2012;42(7):1470-6. https://doi.org/10.1007/s10803-011-1414-7

9. Schiff M, Benoist JF, Aissaoui $\mathrm{S}$, et al. Should metabolic diseases be systematically screened in nonsyndromic autism spectrum disorders? PLoS One. 2011;6(7): e21932. https://doi.org/10.1371/journal.pone.0021932

10. Esparham AE, Smith T, Belmont JM, Haden M, Wagner LE, Evans RG, Drisko JA. Nutritional and metabolic biomarkers in autism spectrum disorders: an exploratory study. Integr Med (Encinitas). 2015;14(2):40-53. PMID: 26770138.

11. Frye RE, Delatorre R, Taylor H, Slattery J, Melnyk S, Chowdhury N, James SJ. Redox metabolism abnormalities in autistic children associated with mitochondrial disease. Transl Psychiatry. 2013;3(6):e273.

https://doi.org/10.1038/tp.2013.51

12. Frustaci A, Neri M, Cesario A, Adams JB, Domenici E, Dalla Bernardina B, Bonassi S. Oxidative stress-related biomarkers in autism: systematic review and metaanalyses. Free Radic Biol Med. 2012;52(10):2128-41. https://doi.org/10.1016/j.freeradbiomed.2012.03.011

13. Dhillon S, Hellings JA, Butler MG. Genetics and mitochondrial abnormalities in autism spectrum disorders: a review. Curr Genomics. 2011;12(5):322-32. https://doi.org/10.2174/138920211796429745

14. Rossignol DA, Frye RE. A review of research trends in physiological abnormalities in autism spectrum disorders: immune dysregulation, inflammation, oxidative stress, mitochondrial dysfunction and environmental toxicant exposures. Mol Psychiatry. 2012;17(4):389401. https://doi.org/10.1038/mp.2011.165

15. Shoffner J, Hyams L, Langley GN, et al. Fever plus mitochondrial disease could be risk factors for autistic regression. J Child Neurol. 2010;25(4):429-34. https://doi.org/10.1177/0883073809342128

16. Kosinovsky B, Hermon S, Yoran-Hegesh R, Golomb A, Senecky Y, Goez H, Kramer U. The yield of laboratory investigations in children with infantile autism. J Neural Transm (Vienna). 2005;112(4):587-96. https://doi.org/10.1007/s00702-004-0198-8

17. Kiykim E, Zeybek CA, Zubarioglu T, et al. Inherited metabolic disorders in Turkish patients with autism spectrum disorders. Autism Res. 2016;9(2):217-23. https://doi.org/10.1002/aur.1507

18. Wijburg FA, Nassogne MC. Disorders of the urea cycle and related enzymes. In: Saudubray JM, van den Berghe G, Walter JH, editors. Inborn Metabolic Diseases Diagnosis and Treatment. 5th ed. 2012. p. 298-324. https://doi.org/10.1007/978-3-642-15720-2_20

19. Braissant O, Henry H. AGAT, GAMT and SLC $\overline{6} A 8$ distribution in the central nervous system, in relation to creatine deficiency syndromes: a review. J Inherit Metab Dis. 2008;31(2):230-9. https://doi.org/10.1007/s10545-008-0826-9

20. Schmidt RJ, Hansen RL, Hartiala J, Allayee H, Schmidt LC, Tancredi DJ, et al. Prenatal vitamins, one-carbon metabolism gene variants, and risk for autism. Epidemiology. 2011;22(4):476-85. https://doi.org/10.1097/EDE.0b013e31821d0e30

21. Grant WB, Soles CM. Epidemiologic evidence supporting the role of maternal vitamin $D$ deficiency as a risk factor for the development of infantile autism. Dermatoendocrinol. 2009;1(4):223-8. https://doi.org/10.4161/derm.1.4.9500

22. Meguid NA, Hashish AF, Amwar M, Sidhom G. Reduced serum levels of 25-hydroxy and 1,25-dihydroxy vitamin D in Egyptian children with autism. J Altern Complement Med. 2010;16(6):641-5. https://doi.org/10.1089/acm.2009.0349

23. McCaddon A, Hudson P, Ellis D, Hill D, Lloyd A. Effect of supplementation with folic-acid on relation between plasma homocysteine, folate, and vitamin B12. Lancet. 2002;360(9327):173.

https://doi.org/10.1016/S0140-6736(02)09395-9

24. Hooshmand B, Solomon A, Kåreholt I, et al. Associations between serum homocysteine, holotranscobalamin, folate and cognition in the elderly: a longitudinal study. Intern Med. 2012;271(2):204-12. https://doi.org/10.1111/j.1365-2796.2011.02484.x

25. Rossignol DA, Frye RE. Melatonin in autism spectrum disorders: a systematic review and meta-analysis. Dev Med Child Neurol. 2011;53(9):783-92. https://doi.org/10.1111/j.1469-8749.2011.03980.x

26. Ghanizadeh A. Increased glutamate and homocysteine and decreased glutamine levels in autism: a review and strategies for future studies of amino acids in autism. Dis Markers. 2013;35(5):281-6. 
https://doi.org/10.1155/2013/536521

27. Weissman JR, Kelley RI, Bauman ML, et al. Mitochondrial disease in autism spectrum disorder patients: a cohort analysis. PLoS One. 2008;3(11):e3815.

https://doi.org/10.1371/journal.pone.0003815

28. Niyazov DM, Kahler SG, Frye RE. Primary mitochondrial disease and secondary mitochondrial dysfunction: Importance of distinction for diagnosis and treatment. Mol Syndromol. 2016;7(3):122-37. https://doi.org/10.1159/000446586

29. Heilstedt HA, Shahbazian MD, Lee B. Infantile hypotonia as a presentation of Rett syndrome. Am J Med Genet. 2002;111(3):238-42.

https://doi.org/10.1002/ajmg.10633

30. Haas RH. Autism and mitochondrial disease. Dev Disabil Res Rev. 2010;16(2):144-53.

https://doi.org/10.1002/ddrr.112

31. Herrero E, Aragon MC, Gimenez C, et al. Inhibition by phenylalanine of tryptophan transport by synaptoso- mal plasma membrane vesicles: implications in the pathogenesis of phenylketonuria. J Inherit Metab Dis. 1983;6(1):32-5.

https://doi.org/10.1007/BF02391190

32. Mazlum B, Anlar B, Kalkanoğlu-Sivri S, Karlı-Oğuz K, Özusta Ş, Ünal F. Late-diagnosed phenylketonuria case presenting with autism spectrum disorder in early childhood. Turk J Pediatr. 2016;58(3):318-22.

https://doi.org/10.24953/turkjped.2016.03.016

33. Iafolla AK, Thomson Jr. RJ, Roe CR, et al. Medium-chain acilCoA dehidrogenase deficiency: clinical course in 120 affected children. J Pediatr. 1994;124(3):409-15. https://doi.org/10.1016/S0022-3476(94)70363-9

34. Andresen BS, Bross P, Udvari S, et al. Tr molecular basis of MCAD deficiency in compound heterozygous patients- is there a correlation between genotype and phenotype? Hum Mol Genet. 1997;6(5):695-707. https://doi.org/10.1093/hmg/6.5.695 